\title{
AS PRESSÕES DOS ALIADOS E A EVOLUÇÃO DA POLÍTICA EXTERNA PORTUGUESA ENTRE 1942 E 1943: DA NEUTRALIDADE À COLABORAÇÃO
}

\author{
Alexandre Luís Moreli Rocha \\ Mestre e doutorando em História das Relações Internacionais \\ Université de Paris 1 - Panthéon-Sorbonne
}

\section{Resumo}

Este artigo é uma reflexão parcial de um estudo mais amplo sobre as relações angloamericanas da década de 1940. Elaborado após um exame exaustivo dos arquivos diplomáticos e militares franceses, o presente trabalho discorre sobre as consequências das rivalidades entre as potências em guerra presentes em Lisboa e seus efeitos sobre o gabinete de Salazar.

\section{Palavras-chave}

Aliados • Segunda Guerra Mundial • Portugal.

\section{Abstract}

This article is a reflection from a more wide-ranging study that is being undertaken to investigate the relations between the Anglo-Americans during the 1940's. Concluded after an exhaustive analysis of both diplomatic and militaries French archives, it explores the consequences of the rivalries between the war powers present in Lisbon and their effects under the Salazar's cabinet.

\section{Keywords}

Grand Alliance • Second World War • Portugal. 
Ao contrário do que pregava o positivismo histórico vigente no que era conhecido como história diplomática clássica até meados do século XX (na qual máxima atenção era dada aos arquivos e às políticas exteriores das grandes potências, à celebração e ao rompimento de tratados e às ações e deliberações dos diplomatas e de seus líderes), raras vezes as decisões dos homens de Estado foram tomadas sem considerar as conjunturas nacionais e internacionais em que se inseriam. Na esteira da reforma epistemológica provocada pela École des Annales, foi o historiador francês Pierre Renouvin quem alargou o conceito de história diplomática para o de história das relações internacionais ao pregar que, embora a relação entre estados permaneça central, uma atenção mais sistemática teria que ser dada não somente à diplomacia, mas também à economia, à estratégia, às fontes domésticas das políticas exteriores, à ideologia e à propaganda, em suma, às "forças profundas", segundo as próprias palavras de Renouvin. ${ }^{1}$

Apesar das inovações trazidas pela escola francesa, a análise da história de Portugal e de suas relações com os Estados Unidos da América e com a Inglaterra durante a Segunda Guerra Mundial, a ser desenvolvida neste artigo, revela-se um bom exemplo para mostrar que as correntes historiográficas nacionais assimilaram de forma diferente os novos conceitos e metodologias desenvolvidos por Renouvin.

Em um governo centralizador, em que o homem era mais forte que as instituições, em que a força e o poder do líder eram categóricos, a análise das decisões tomadas em Portugal no início da década de 1940 torna-se um verdadeiro desafio para o historiador que procura desenvolver uma história mais plural e crítica dos processos de tomada de decisão operados por Oliveira Salazar.

A historiografia anglo-americana, por exemplo, tem em regra uma preferência pela análise de fontes primárias que conduzam o historiador à discriminação dos "processos de tomada de decisão" (decision making process) e, por conseguinte, para as fontes de pesquisa histórica primárias oriundas das relações de poder no ápice da hierarquia de um governo. ${ }^{2}$ Como ressalta o

\footnotetext{
${ }^{1}$ RENOUVIN, Pierre; DUROSELLE, Jean-Baptiste. Introduction à l'histoire des relations internationales. 4a ed. Paris: Armand Colin, 1991, capítulo 11.

${ }^{2}$ Interessante notar que o próprio formato dos programas de doutoramento no sistema de pós-graduação anglo-americano contribui para uma seleção mais limitada de fontes primárias. Por exemplo, em geral, o limite para as teses vai de 80 a 100 mil palavras, enquanto que no sistema latino (francês, por exemplo) encontram-se dissertações com o dobro, às vezes o triplo ou o quádruplo desse tamanho. Alguns trabalhos anglófonos, que analisam de forma mais geral o tema aqui tratado, revelam esse perfil da escola anglo-americana: WEINBERG, Gerhard. A world at arms. Cambridge: Cam-
} 
historiador americano Matthew Connelly, a grande crítica dessa escola sobre a transformação da história diplomática em história das relações internacionais (ou international history como é conhecida no mundo anglófono) é que o formato proposto por esta última seria demasiado extenso para um trabalho de pesquisa que resta majoritariamente individual no mundo dos historiadores. ${ }^{3}$ Nesse sentido, o risco de estudos sem profundidade seria alto, sem mencionar as grandes chances de, ao manipular diversas fontes primárias nacionais em diversas temáticas, o pesquisador perder-se em meio a tal complexidade e não alcançar seu principal objetivo: reconstruir a rede de relações internacionais em questão. Nas duas obras em que analisa as relações entre Inglaterra e Portugal nos anos 1930 e 1940, o historiador inglês Glyn Stone, ${ }^{4}$ por exemplo, utiliza primordialmente as fontes primárias inglesas oriundas das mais altas esferas do poder (como do Cabinet, do prime minister e do Foreign Office). ${ }^{5}$

$\mathrm{Na}$ escola portuguesa, há trabalhos como Os Açores e o contrôlo do Atlântico (Lisboa: Asa, 1993), de Antonio José Telo, Roosevelt, Churchill e Salazar. A luta pelos Açores (1941-1945) (s. 1.: Ediclube, 1995), de José Freire Antunes e AAliança inglesa e a neutralidade colaborante de Portugal (In: Boletim do Instituto Histórico da Ilha Terceira, vol. LI-LII. Angra do Heroísmo, 1993-1994, p. 13-31), de Luis Andrade, que destacam primordialmente as relações militares e diplomáticas internacionais de Portugal, utilizando o mesmo gênero de fontes que os ingleses (e algumas vezes nem mesmo fontes primárias não publicadas, como é o caso do artigo do professor Andrade que se refere mais diretamente à temática a ser desen-

bridge University Press, 1994. GADDIS, John L. The United States and the origins of the Cold War (1941-1947). Nova Iorque: Columbia University Press, 2000. LEFFLER, Melvyn P; PAINTER, David S. Origins of the Cold War: An international history. $2^{\mathrm{a}}$ ed. Nova Iorque: Routledge, 2007. e REYNOLDS, David. From World War to Cold War. Nova Iorque: Oxford University Press, 2007. Faz-se importante destacar, entretanto, as vozes dissidentes que pedem, já há décadas, mais atenção dos historiadores para os arquivos estrangeiros e para análises estruturais, como: MAY, Ernest R. The decline of diplomatic history. In: BILLIAS, George Athan; GROB, Gerald N. (org.). American history: retrospect and prospect. Nova Iorque: [s. n.], 1971; e KOLKO, Gabriel; Joyce. The limits of power: The World and United States Foreign Policy (1945-1954). [s. 1.]: Harper \& Row, 1972.

${ }^{3}$ CONNELLY, Matthew. A diplomatic revolution. Nova Iorque: Oxford UP, 2002, p. IX.

${ }^{4}$ STONE, Glyn. The oldest Ally. Britain and the Portuguese connection (1936-1941). Grã-Bretanha: The Royal Historical Society, 1994; e STONE, Glyn A. The official British attitude to the AngloPortuguese Alliance, 1910-1945. In: Journal of Contemporary History, vol. 10, n. 4, outubro 1975. Londres, 1975, p. 729-746.

${ }^{5}$ Tratam-se respectivamente dos arquivos ingleses (National Archives - Public Record Office - Londres, UK), do órgão coletivo máximo de decisão dentro do governo inglês (Série CAB), do gabinete do primeiro ministro inglês (Série PREM) e do Ministério inglês encarregado das Relações Exteriores (Série FO). 
volvida no presente texto, mas que se baseia exclusivamente em fontes secundárias e na coletânea de documentos diplomáticos de Portugal dos anos 1940 publicada pelo Ministério dos Negocios Estrangeiros ${ }^{6}$ que, como toda obra do gênero, porta documentos originais selecionados para publicação, não oferecendo, muitas vezes, uma perspectiva completa e imparcial sobre o tema em análise).

Entretanto, os portugueses parecem colocar-se mais próximos dos franceses ao produzir em diversos trabalhos uma análise mais plural da história de Portugal do mesmo período. ${ }^{7}$ Ao lado de La Méditerranée et le monde méditerranéen à l'epoque de Philippe II (Paris: Armand Colin, 1949), de Braudel, e Histoire des relations internationales ( 4 tomos. $2^{\text {a }}$ ed. Paris: Hachette, 1954), de Renouvin, estas obras provam que é possivel realizar uma pesquisa individual que apresente, ao mesmo tempo, uma análise dos processos de tomada de decisão e das estruturas econômicas, culturais e sociais que os influenciaram, utilizando criticamente uma multiplicidade de fontes. Nesse sentido, destacam-se os trabalhos dos portugueses Fernando $\operatorname{Rosas}^{8}$ e Fernanda Rollo ${ }^{9}$ que utilizam não somente fontes primárias oriundas de arquivos diplomáticos, mas também de diversos ministérios do governo português, da iniciativa privada, da imprensa, de entrevistas e de dados estatísticos, além de um extenso rol de fontes secundárias e de arquivos de outros países, como dos Estados Unidos, da Inglaterra, da França e de organismos internacionais. Outro exemplo dessa proximidade (e influência) entre a escola francesa e a portuguesa verifica-se na tese de doutorado defendida recentemente na Université de Paris 1 - Panthéon-Sorbonne pelo historiador português Pedro Cantinho Pereira ${ }^{10}$ que desenvolve uma complexa problemática sobre a história de Portugal e o início da integração europeia, ao utilizar, por exemplo, arquivos diplomáticos, pessoais, comerciais, políticos, militares e estatísticos franceses, portugueses, belgas, ingleses, americanos e

\footnotetext{
${ }^{6}$ PORTUGAL (Ministério dos Negócios Estrangeiros). Dez anos de política externa (1936-1947): a nação portuguesa e a Segunda Guerra Mundial. 15 volumes, Lisboa: Imprensa Nacional, 1961-1992. ${ }^{7}$ Interessantes exemplos são os artigos de José de Matos-Cruz (Portugal - o cinema da guerra), de José M. P. de Oliveira (A guerra vista através da imprensa portuguesa) e de Fernando Rosas (A indústria portuguesa durante a Segunda Guerra Mundial) reunidos na obra coletiva Portugal na Segunda Guerra Mundial. Contributos para uma reavaliação. Lisboa: Dom Quixote, 1989.

${ }^{8}$ ROSAS, Fernando. Portugal entre a paz e a guerra (1939-1945). Lisboa: Editorial Estampa, 1995, p. 469-484.

${ }^{9}$ ROLLO, Fernanda. Portugal e o Plano Marshall. Lisboa: Editorial Estampa, 1994, p. 327-355.

${ }^{10}$ Publicada em: PEREIRA, Pedro Cantinho. Portugal e o início da construção europeia (19471953). [s. 1.]: Ministério dos Negócios Estrangeiros de Portugal, 2006.
} 
de organismos supranacionais europeus que surgiam na época, um marco na pesquisa histórica transnacional luso-francesa.

Nesse contexto, o texto aqui apresentado, ao ter sido desenvolvido no Institut Pierre Renouvin da Sorbonne (que continua a desenvolver a evolução historiográfica iniciada pelo seu inspirador), ao buscar trazer uma nova perspectiva na análise das relações de Portugal com as Nações Unidas entre 1942 e 1943 e, principalmente, ao utilizar pela primeira vez os arquivos nacionais franceses para tal empreitada, caminha, por conseguinte, ao encontro da tradição francesa da história das relações internacionais.

Portugal aparece hoje como uma pequena nação que conservou um grande império colonial. Para defender a metrópole e o império, só resta a Salazar contar com o bom direito. Qualquer ameaça à neutralidade portuguesa, de onde quer que venha ou se produza, arrisca comprometer todo um edifício pacientemente construído, podendo até mesmo comprometer a sobrevivência do império (sr. De Boysson, adido naval francês em Lisboa, 12/05/1942). ${ }^{11}$

Até 1942, face aos avanços do Eixo e à formação da aliança da URSS com os anglo-americanos, a visão do governo de Oliveira Salazar sobre o futuro da Europa colocava Portugal em uma posição de destaque: em um mundo equilibrado entre o Eixo e os Aliados, no caso de uma paz de compromisso, Lisboa seria uma das raras capitais capazes de colaborar simultaneamente, no plano internacional, com nações possuindo estruturas políticas radicalmente diferentes umas das outras. Nessa hipotética conjuntura, o perfil corporativista do regime salazarista, de um lado, e as relações históricas com a Inglaterra, de outro, constituiriam importantes trunfos para o líder português.

Entretanto, a partir das vitórias dos Aliados no norte da África, da reação soviética perante as tropas alemãs, da diminuição da força militar do Eixo e do desaparecimento de um cenário onde Lisboa teria um lugar de primeiro plano, o presidente Salazar seria levado a procurar uma aproximação com as Nações Unidas, especialmente ao lado dos ingleses e dos estadunidenses. Encarado como ponto vital de articulação no oceano Atlântico, o arquipélago português dos Açores seria a principal, mesmo se não única, causa para o início de complexas negociações diplomáticas que provocariam importantes mudanças na neutralidade portuguesa.

\footnotetext{
${ }^{11}$ Arquivo do Ministério francês da Defesa - Château de Vincennes (AMFD) - Série 2 BB7 Li 3 - 1939/1947. Resumo de informação secreto n. 18, datado de 12/05/1942, da Legação francesa em Portugal ao almirantado francês, Marinha.
} 


\section{A neutralidade portuguesa, do triunfo ao obstáculo}

Na medida em que os anos de guerra passavam, a neutralidade portuguesa passou de uma solução conveniente a um problema extremamente difícil de se administrar.

Anunciada em maio de 1939 e confirmada logo quando do início dos conflitos, a política exterior escolhida por Salazar tomava contornos diferentes da sua congênere existente no período entre 1914 e 1916 (que foi fortemente subordinada aos interesses estratégicos britânicos durante a Primeira Grande Guerra $)^{12}$ e dava maior liberdade de manobra ao governo português, devido ao enfraquecimento da hegemonia inglesa frente às vitórias e aos projetos alemães para a Europa, especialmente depois dos desdobramentos da Guerra Civil espanhola, mesmo se para alguns historiadores portugueses, como Luis Andrade, "se não tivesse sido do interesse da Grã-Bretanha que Portugal fosse neutral durante a Segunda Guerra Mundial, pensamos que não o teria sido". ${ }^{13}$

A neutralidade permitia explorar, em benefício de Portugal, sem colocar em risco suas relações exteriores, as contradições existentes entre as grandes potências, e de buscar, nas fraturas existentes entre estas, um possível espaço de autonomia política e econômica. ${ }^{14}$ Contudo, o fraco potencial militar de Portugal e a extensão de seu império colonial obrigavam os dirigentes desse país a uma política de extrema prudência. Apesar do discurso oficial que preconizava a unidade geográfica portuguesa, a Salazar não era permitido cometer erros, pois o risco de comprometer não somente o presente, mas também o futuro de seu país era considerável.

O presidente do Conselho de Ministros português sempre defendeu publicamente a neutralidade como estando ao serviço do interesse nacional, o que pouco dissimulava a delicada posição em que o país se encontrava, sobretudo pela dependência do comércio marítimo (em constante tensão por causa do conflito) para a quase totalidade de seu abastecimento. Nesse complexo contexto, Portugal se mostrava internamente uma nação dividida e paralisada. Observando-se a

\footnotetext{
${ }^{12}$ ANDRADE, Luís Manoel Vieira de. A importância geoestratégica dos Açores nas duas guerras mundiais. In: Os Açores e as dinâmicas do Atlântico: dos descobrimentos à II Guerra Mundial. Angra do Heroísmo, 1989, p. 1.391. FERREIRA, José Medeiros. Os Açores nas duas guerras mundiais. In: Os Açores e as dinâmicas do Atlântico: dos descobrimentos à II Guerra Mundial. Angra do Heroísmo, 1989, p. 74. STONE, Glyn A., op. cit., 1975, p. 729-732.

${ }^{13}$ ANDRADE, Luis. A Aliança inglesa e a neutralidade colaborante de Portugal. In: Boletim do Instituto Histórico da Ilha Terceira, vol. LI-LII. Angra do Heroísmo, 1993-1994, p. 15.

${ }^{14}$ AMFD - Série 2 BB7 Li 3 - 1939/1947. Resumo de informação secreto n. 26, datado de 08/09/1942, da Legação francesa em Portugal ao almirantado francês, Marinha.
} 
evolução da opinião pública, constata-se que a massa foi constantemente favorável à causa aliada, mas que a parcela apoiadora dos alemães, apesar de relativa, era de qualidade e posicionada sobretudo na aristocracia e no meio intelectual e militar jovem e sua influência era consideravelmente grande, principalmente na época em que a vitória do Reich parecia provável. ${ }^{15}$

Além disso, o próprio Salazar (e ao menos uma parte importante de seus próximos) era também pró-Eixo, e nem tanto por convicção, por gosto ou por interesses de ordem pessoal, mas principalmente por medo do comunismo, por ideologia e, sobretudo, pelo medo de ser obrigado a deixar o poder e de prestar contas, pois a vitória do Eixo significaria a certeza da manutenção do regime e a dos Aliados, o futuro incerto.

Todavia, na medida em que os anos de guerra passavam, a ameaça de enfrentar, qual que fosse a hesitação de Lisboa, as divisões blindadas alemãs a leste ou os canhões dos couraçados anglo-americanos a oeste aumentava as preocupações na capital portuguesa. Como prova, admitia-se, pela primeira vez, mesmo que sem entusiasmo e sem consequências práticas imediatas, que o desejo da neutralidade não poderia ser superior ao interesse da nação e que o país não deveria se render à ideia de que não teria que lutar um dia.

Essa evolução deveu-se a uma série de acontecimentos que abalaram a política exterior do país a partir de 1942, com importantes repercussões sobre sua neutralidade, mesmo se Portugal continuasse preferindo pagar a guerra a encampá-la.

Um dos desafios, por exemplo, era o de administrar os diálogos e as concessões inevitáveis e o de dar provas tangíveis de boa vontade (mesmo que contra seus interesses) aos dois campos em guerra, como aconteceu quando da invasão japonesa do Timor oriental. ${ }^{16}$ Após essa ação das tropas de Tóquio, as relações com o Japão passaram a ser tensas, levando Lisboa ao seu primeiro sério dilema perante o Eixo, dado que o discurso oficial do regime sempre defendeu incondicionalmente a integridade das colônias, tidas como sinônimo de honra e de razão de ser da nação.

Outro episódio importante dentro da intrincada manutenção da política portuguesa durante a evolução da guerra foram as crescentes tensões entre o Brasil e o Eixo após a aproximação ocorrida entre Washington e Rio de Janeiro em

\footnotetext{
${ }^{15}$ Ibidem.

${ }^{16}$ Possessão portuguesa datada do século XVI que, fazendo parte da primeira linha de defesa da Austrália, foi tomada primeiramente pelos britânicos e, semanas depois, pelos japoneses. TELO, Antonio José. Portugal na Segunda Guerra (1941-1945. Lisboa: Vega, vol. 1, 1991, p. 43-66.
} 
1942. Os ataques feitos aos navios brasileiros pelos submarinos alemães com a finalidade de perturbar as comunicações marítimas entre os Atlânticos sul e norte foram acompanhadas por Lisboa com uma grande inquietude e solidariedade, especialmente porque a manutenção de uma forte relação luso-brasileira era, para Portugal, uma necessidade moral e material, e também porque o gigante sulamericano prolongava a presença lusitana sobre o hemisfério ocidental, além de o regime de Getúlio Vargas ser um ponto de apoio à política de Estado de Salazar.

A importância da antiga colônia era tão significativa que sua eventual entrada em guerra aumentaria não somente o isolamento político de Portugal, mas tornaria ainda maior o preço da manutenção da neutralidade devido às pressões populares a favor dos brasileiros que certamente se seguiriam.

Assim, confirmando os temores do gabinete de Salazar, em agosto de 1942, a entrada do Brasil em guerra ao lado das Nações Unidas ${ }^{17}$ e contra dois países (Alemanha e Itália) com os quais Portugal mantinha relações normais, não deixou de causar em Lisboa uma forte repercussão. Ademais, tal atitude agravava a já difícil situação do governo português, particularmente com relação à integridade das ilhas dos Açores, estrategicamente localizadas no meio do Atlântico norte e há algum tempo visadas por Londres e Washington para serem controladas pelo exército brasileiro como escala vital para as tropas aliadas. Sem mencionar que ruía a expectativa de Salazar de constituir uma zona de paz latina e cristã, composta dos regimes ibéricos, da França de Pétain e do Brasil de Vargas. ${ }^{18}$

Publicamente e durante vários dias, a imprensa portuguesa dedicou inúmeros editoriais a esse acontecimento e o governo transmitia ao Rio de Janeiro seus sentimentos de estima e de solidariedade moral perante a atitude de defender aquilo que acreditava ser seu direito. Essa foi uma das raras ocasiões que permitiu aos portugueses manifestar publicamente seus sentimentos de simpatia à causa aliada que agrupava, como dito, uma parte significativa da população.

Mesmo se, em princípio, tal postura pudesse causar ruídos nas relações com Berlim, o governo alemão não demandou garantias sobre as atitudes futuras de Lisboa. Na verdade, o Reich tinha consciência de que o exército português estava disperso pelo império e que ele não representava nenhuma ameaça.

${ }^{17}$ CERVO, Amado Luiz; BUENO, Clodoaldo. Historia da política externa do Brasil. $2^{\mathrm{a}}$ ed. Brasília: Editora Universidade de Brasília, 2002, p. 263.

${ }^{18}$ ROSAS, Fernando, op. cit., 1995, p. 76. 
Todavia, mesmo se a Alemanha não tinha razões para se incomodar com as manifestações portuguesas de apoio moral "platônico" ao Brasil, um pouco "forçadas e exageradas", segundo o cônsul francês em Porto, ${ }^{19}$ o que realmente importava era o perigo da concretização de uma ocupação dos Açores pelas tropas brasileiras.

Considerando as vantagens da posição geoestratégica do Brasil (que permitia um domínio de uma parte significativa de um oceano que conhecia a batalha mais importante do conflito até então), ${ }^{20}$ abria-se claramente uma nova política atlântica à qual Portugal não podia ficar indiferente em função de suas possessões africanas e das bases aeronavais que o país detinha nesse oceano.

Não menos importante, a venda de volfrâmio, ${ }^{21}$ apesar de constituir um trunfo para as finanças do país, completava o rol dos sensíveis dossiês que Salazar tinha que administrar. Desde 1941, as exportações desse mineral para os dois blocos em guerra aumentavam fortemente (chegando a representar 63\% do comércio total de exportações portuguesas durante o primeiro trimestre de 1942, sem mencionar a explosão de seu preço, aumento que chegou a 3.500\% em 1942). ${ }^{22}$ Diante do aumento do comércio do produto, os Aliados exerceram, desde a primavera de 1942, fortes pressões sobre Lisboa que, se não proibiram as exportações para o Eixo, obrigaram Salazar a combater os contrabandos (com os quais a Alemanha reforçava suas compras).

A compatibilização de todas essas complicações com a neutralidade era agravada por um outro fato importante: o Tratado de Amizade e de Não Agressão de 1939-40 celebrado entre Portugal e Espanha. Em função desse acordo, Salazar acreditava que qualquer operação aliada em território português (como nos Açores) resultaria em uma reação da Espanha, que encontraria a desculpa necessária para invadir o vizinho, resultando no engajamento da península e em um provável ataque alemão sobre Gibraltar.

\footnotetext{
${ }^{19}$ Arquivo do Ministério francês dos Negócios Estrangeiros - Quai d'Orsay (AMFNE) - Série Guerre 1939-1945 - Vichy, sub-série Europe, vol. 662. Carta n. 38, datada de 28/08/1942, do cônsul francês em Porto a Pierre Laval, ministro e secretário de Estado francês para os Negócios Estrangeiros em Vichy.

${ }^{20}$ GIRAULT, René; FRANK, Robert; THOBIE, Jacques. La loi des géants (1941-1964). Paris: Editions Payot \& Rivages, 2005, p. 73.

${ }^{21}$ Principal fonte de extração do tungstênio, metal utilizado para a produção de aços para blindados, peças de tanques, aviões, motores etc.

${ }^{22}$ Instituto Nacional de Estatísticas de Portugal (ROSAS, Fernando, op. cit., 1995, p. 148).
} 
O agravamento da situação de Portugal era tão notório que até a rede diplomática francesa chegou a especular sobre planos dos Aliados para provocar a entrada em guerra da península e de aceitar a invasão alemã sobre Madri e Lisboa para que os navios ingleses (e os produtos do Império português) destinados ao abastecimento de Portugal, e que raramente retornavam cheios à Grã-Bretanha, fossem colocados à disposição das Nações Unidas. ${ }^{23}$

Apesar de tudo, os dirigentes portugueses, ainda em 1942, não estavam certos sobre o futuro vencedor da guerra e, consequentemente, sobre quem seria o futuro inimigo, pois a esse caberia a tarefa de refazer à sua maneira o mapa da Europa e do mundo. Lisboa sabia que seria preciso continuar a dar provas de boa vontade alternativamente aos dois lados em conflito, dos quais dependia inteiramente a situação de Portugal e de seu império.

\section{O embate entre a Aliança Secular e a potência estadunidense}

Apesar de possuir raízes na Idade Média (foi celebrada em 1373) a dita "aliança mais antiga do mundo" 24 conheceu uma evolução ao longo do tempo, constituindo o século XIX e as primeiras décadas do XX um período de forte supremacia de Londres.

Entretanto, durante os primeiros anos da guerra, os sucessos do Eixo na Europa e na Ásia impressionaram Lisboa e ameaçaram a forte influência britânica sobre Portugal, mesmo considerando que subsistia uma forte ligação comercial e uma forte propaganda inglesa em solo português. ${ }^{25}$ Essa proximidade, entretanto, seria colocada à prova não só pelas conquistas de Hitler, mas, sobretudo, pelo crescimento do peso internacional dos Estados Unidos após Pearl Harbor. O surgimento da superpotência começava a se fazer notar em Portugal já em 1942, como ressaltou o adido naval francês em Lisboa, sr. De Boysson, que acompanhava atentamente a evolução das forças internacionais em solo português: "A posição dos Estados Unidos em Portugal ganha importância e tende

\footnotetext{
${ }^{23}$ AMFD - Série 2 BB7 Li 3 - 1939/1947. Resumo de informação n. 17, datado de 28/01/1942, do adido naval da Legação francesa em Portugal ao almirantado francês, Marinha.

${ }^{24}$ Sobre o assunto, ver: STONE, Glyn, op. cit., 1994. e ROSAS, Fernando. O salazarismo e a Aliança Luso-Britânica. Lisboa: Fragmentos, 1988.

${ }^{25}$ AMFD - Série 2 BB7 Li 3 - 1939/1947. Resumo de atividade n. 2, datado de 27/01/1942, da Legação francesa em Portugal ao almirantado francês, Marinha. Sobre o assunto, ver: BARROS, Julia Leitão. Anglofilia e germanofilia em Portugal durante a Segunda Guerra Mundial. In: CARRILHO, Maria (org.). Portugal na Segunda Guerra Mundial: Contributos para uma reavaliação. Lisboa: Publicações Dom Quixote, 1989, p. 91-136.
} 
a tomar o primeiro lugar, em detrimento dos britânicos". ${ }^{26}$ Entretanto, mesmo considerando que a própria imprensa portuguesa começava a valorizar a força de Washington, seus líderes históricos e sua capacidade de intervenção militar, os estadunidenses não se mostravam ainda preparados a se encarregar totalmente da posição de superpotência. Continuava o adido francês:

Vista de Lisboa, a situação dos Estados Unidos parece cada dia mais preponderante. (...) Os representantes americanos em Lisboa alcançam progressivamente, devido às circunstâncias, seus colegas ingleses. Mas ainda vai levar um tempo até que os ianques consigam conquistar a noção de império e de suas novas responsabilidades. ${ }^{27}$

Mesmo considerando-se a política, o poder militar e outros elementos mais contemporâneos aos estudos das relações internacionais e da capacidade de influência e coação dos estados, como a economia, a cultura, a demografia e a opinião pública, Jean-Baptiste Duroselle, em seu Todo império perecerá ${ }^{28}$ ensina que resta ainda um importante aspecto a compor o conceito de "potência": a ambição. A percepção de "potência" e sua escolha como linha determinativa da política exterior e interior de um país, como proclamou o general De Gaulle em 1945 (“... essa potência, ah! Possa ela tornar-se a grande ambição nacional!”), ${ }^{29}$ também fazem parte de sua própria materialização. Era o que, contudo, faltava ao corpo diplomático e a alguns setores do governo estadunidense durante os primeiros anos do país em guerra, concedendo, assim, uma sobrevida ao cambaleante peso inglês na ordem internacional. ${ }^{30}$

De fato, os princípios previstos para governar o mundo no pós guerra, consolidados na Carta do Atlântico de 1941, ${ }^{31}$ afastavam-se do padrão ibérico do exercício do poder (e, em certos pontos, também do inglês), revelando uma

\footnotetext{
${ }^{26}$ AMFD - Série 2 BB7 Li 3 - 1939/1947. Resumo de atividade n. 14, datado de 11/07/1942, da Legação francesa em Portugal ao almirantado francês, Marinha.

${ }^{27}$ AMFD - Série 2 BB7 Li 3 - 1939/1947. Resumo de atividade n. 19, datado de 15/09/1942, da Legação francesa em Portugal ao almirantado francês, Marinha.

${ }^{28}$ DUROSELLE, Jean-Baptiste. Todo império perecerá. Brasília: Editora Universidade de Brasília, 2000, p. 391.

${ }^{29}$ DE GAULLE, Charles. Mémoires de guerre, $3^{\circ}$ tomo. Paris: Plon, 1959, p. 454.

${ }^{30}$ AMFD - Série 2 BB7 Li 3. 1939/1947. Resumo de atividade n. 20, datado de 29/09/1942, da Legação francesa em Portugal ao almirantado francês, Marinha.

${ }^{31}$ Declaração de princípios assinada entre o presidente dos Estados Unidos e o primeiro-ministro do Reino Unido (Carta do Atlântico) no dia 14 de agosto de 1941. Disponível em: http://www. nato.int/docu/fonda/b410814a.htm], acesso em: 08/01/09.
} 
visão de mundo mais liberal (mais wilsoniano, segundo Roosevelt) ${ }^{32}$ onde reinaria a democracia política e a liberdade econômica. Como lembra GeorgesHenri Soutou, ${ }^{33}$ a percepção do presidente estadunidense foi depreciada pelos líderes europeus e a sua ideia de "potência" afastava-se daquela presente nas mentes mais conservadoras da Europa, para as quais esse conceito se explicava sobretudo por uma ideia de liderança civilizatória e imperialista. ${ }^{34}$

Mesmo que as rivalidades que despontavam para o pós-guerra viessem a impor uma nova maneira de se entender o conceito de "potência" (ou superpotência), tão importante quanto ser reconhecido como uma era ter consciência das responsabilidades que ela comportaria. Somente ao tomar consciência da dimensão de sua força (como de sua capacidade de impor vontades ou de influenciar decisões) e somente após controlar à perfeição os meios disponíveis para alcançar seus objetivos (econômicos, diplomáticos, militares etc.) é que os Estados Unidos estariam aptos a: fazer face à dominação inglesa tanto em Portugal como no bloco ocidental, estabilizar as relações atlânticas e responder às novas demandas mundiais. Um processo de amadurecimento que se estenderia ainda por alguns anos.

\section{$\mathbf{0}$ arquipélago português dos Açores e a definição da estratégia aliada}

$\mathrm{O}$ desenvolvimento da indústria aeronáutica durante o entre guerras deu uma nova dimensão aos dispositivos de controle do Atlântico. "A superioridade aérea deveria permitir uma revolução estratégica", lembram Jean Louis Dufour e Maurice Vaïsse sobre as projeções da época. ${ }^{35}$

O progresso da aviação militar durante a década de 1930 teve uma forte inspiração comercial: se era possível, com uma escala nos Açores, transportar passageiros da Europa até a América, uma guerra aérea intercontinental seria, então, concebível.

${ }^{32}$ GADDIS, John Lewis. The United States and the origins of the Cold War (1941-1947). Nova Iorque: Columbia UP, 2000, p. 11.

${ }^{33}$ SOUTOU, Georges-Henri. La guerre de cinquante ans: Les relations Est-Ouest 1943-1990. Paris: Librairie Arthème Fayard, 2001, p. 24.

${ }^{34}$ Como se nota em outra declaração de De Gaulle, feita também em 1945: "No mundo, a Inglaterra e a França são as duas principais potências, cuja missão é de guiar as outras nações em direção ao desenvolvimento material, a uma maior maturidade política e a um nível mais elevado de civilização". GIRAULT, René. Les décideurs français et leur perception de la puissance française en 1948. In: GIRAULT, René; FRANK, Robert (org). La puissance française en question 1945-1949. Paris: Publications de la Sorbonne, 1988, p. 13.

${ }^{35}$ DUFOUR, Jean-Louis; VAÏSSE, Maurice. La guerre au XXe siècle. Paris: Hachette Livre, 2003, p. 56. 
Esta ideia já havia, antes mesmo do início dos combates, chamado a atenção de Washington (como mostram os planos de defesa Rainbow), ${ }^{36}$ particularmente porque a possibilidade teórica coincidia com o despertar das ambições alemãs, único país cuja capacidade técnica no domínio da aviação comercial era comparável à dos Estados Unidos. ${ }^{37}$ Entretanto, até a derrota dos franceses, as decisões de Hitler e da Luftwaffe (a força aérea alemã) não representaram grande perigo para Washington ou para os Açores, ${ }^{38}$ confirmando a hipótese dos historiadores franceses René Girault e Robert Frank, segundo os quais o Atlântico ainda era muito vasto para que algum "atlantismo" pudesse existir. ${ }^{39}$

Mesmo se no fim dos anos 30 a neutralidade e o isolacionismo se sobrepunham a uma tomada de posição estadunidense mais ostensiva contra o Eixo, os militares dos dois lados do oceano tinham consciência de que o hemisfério ocidental representava, em potencial, uma base sólida, de uma grande capacidade industrial, rica em matérias primas e em recursos humanos, a partir da qual seria possível organizar uma contraofensiva vitoriosa, mesmo se a Europa e a Ásia estivessem dominadas por potências inimigas. ${ }^{40} \mathrm{O}$ pilar fundamental de um tal plano seria, primeiramente, a defesa da América e dos trampolins (entre eles, as ilhas portuguesas) a partir dos quais se poderia organizar um ataque contra o continente.

Dessa forma, a grande mudança nos estudos estadunidenses sobre o controle aéreo do Atlântico foi a diretiva de 23 de março de 1939 do War Department ${ }^{41}$ cujas conclusões (além de confirmar a existência de uma ameaça potencial para os anos seguintes) consolidavam a ideia segundo a qual a segurança dos Estados Unidos dependia da continuidade do controle do Atlântico pela marinha inglesa

\footnotetext{
${ }^{36}$ Estudos de guerra da Marinha e do Exército americano prevendo, antes de 1939, quais seriam as reações possíveis contra um ataque ao território americano. CONN, Stetson; FAIRCHILD, Byron. The framework of Hemisphere Defense. Washington D. C.: Center of Military History, 1989, p. 7-9. ${ }^{37}$ DOISE, Jean; VAÏSSE, Maurice. Diplomatie et outil militaire (1871-1969). Paris: Imprimerie Nationale, 1987, p. 336.

${ }^{38}$ TELO, Antonio José. Os Açores e o contrôlo do Atlântico (1898/1948). Lisboa: Asa Literatura, 1993, p. 297.

${ }^{39}$ GIRAULT, René; FRANK, Robert. Turbulente Europe et nouveaux mondes (1914-1941). Paris: Editions Payot \& Rivages, 2004, p. 394. Segundo o historiador americano Melvyn Leffler, os oficiais americanos começariam a refletir sobre segurança nacional e rede de bases militares para o pós-guerra somente entre 1943 e 1944. LEFFLER, Melvyn P. National Security and US Foreign Policy. In: LEFFLER, Melvyn P.; PAINTER, David S (org.). Origins of the Cold War: An international history. $2^{\text {a }}$ ed. Nova Iorque: Routledge, 2007 , p. 17.

${ }^{40}$ DUROSELLE, Jean-Baptiste. Historie des relations internationales de 1919 à 1945. Tomo I. $12^{\mathrm{a}}$ edição. Paris: Dalloz, 2001, capítulo 6.

${ }^{41}$ TELO, Antonio José, op. cit., 1993, p. 301.
} 
(em virtude das fragilidades defensivas da costa leste do país que perdurou até 1942 com somente uma divisão operacional e uma fraca força aeronaval próprias ali presentes) e ressaltavam a importância da revisão das relações com Portugal, no sentido de uma aproximação mais estreita.

Até Pearl Harbor, o arquipélago dos Açores era considerado como uma das raras, entretanto efetivas, razões para engajar os Estados Unidos em guerra: o Estado-maior estadunidense tinha decidido que somente uma ameaça às ilhas atlânticas ou a Dakar poderia levar o país a intervir durante essa fase da guerra. ${ }^{42}$ Já a partir de 1942, o arquipélago entra em um novo contexto geoestratégico militar (agora ofensivo) para viabilizar a vitória aliada.

Com a declaração de guerra, os estadunidenses inspiraram-se nos preceitos de Clausewitz e na tradição militar iniciada por Grant e Sherman (vencedores da Guerra Civil). ${ }^{43}$ Para eles, a estratégia era vencer o inimigo com golpes fortes e da maneira mais frontal possível (com a França como campo de batalha e as ilhas atlânticas como peças fundamentais da logística de operação). Em seguida, o importante seria criar uma forte aliança com a Inglaterra e com a China, estabelecer uma aproximação com a URSS evitando sua derrota frente ao Reich, renovar a Liga das Nações, combater as zonas de domínio exclusivo dos impérios europeus tradicionais e consolidar a defesa do hemisfério com uma rede de bases aeronavais. ${ }^{44}$

Já em Londres, os ingleses tinham outros objetivos. A Inglaterra sabia que ela não poderia ganhar a guerra sem os Estados Unidos e que o poder europeu e os impérios tradicionais estavam em crise. Dessa forma, dois princípios diretores diferenciavam as ações britânicas das estadunidenses : vencer o Eixo pelos flancos e não frontalmente, primeiro porque eles não teriam os meios para tanto e segundo porque essa estratégia permitiria desviar as forças aliadas em direção às zonas que interessavam mais aos impérios europeus, contribuindo, assim, à sua manutenção. Ademais, dever-se-ia reduzir ao máximo a expansão soviética, pois

\footnotetext{
${ }^{42}$ Entre vários planos, em um memorando de setembro de 1940, o Joint Chiefs of Staff propôs a ocupação preventiva dos Açores pelos Estados Unidos em caso de ataque da península pelo Eixo. Se os alemães entrassem em Dakar, dever-se-ia ocupar a zona de Natal no Brasil. Se houvesse um colapso inglês, dever-se-ia ocupar todos os pontos do Atlântico sensíveis com relação à defesa do hemisfério, da Groenlândia até Natal, passando pelos Açores. TELO, Antonio José, op. cit., 1993, p. 326. Para o assunto, ver também ANDRADE, Luis M. Vieira de. Os Açores, A Segunda Guerra Mundial e a Nato. $1^{\text {a }}$ ed. Ponta Delgada: Impraçor, 1992, p. 65-83.

${ }^{43}$ GIRAULT, René; FRANK, Robert; THOBIE, Jacques, op. cit., 2005, p. 40-44.

${ }^{44}$ DUROSELLE, Jean-Baptiste, op. cit., 2001, p. 372.
} 
Londres ainda trabalhava com a mentalidade estratégica que marcou o século XIX: a das zonas de influência. Nesse contexto, uma presença de Moscou mais a oeste enfraqueceria a autoridade inglesa no continente europeu. ${ }^{45}$

Os objetivos diferentes das duas grandes potências aliadas provocariam várias divergências ao longo dos anos 1940, algumas vezes afetando a forte "relação especial”46 existente entre Londres e Washington. Nesse contexto, Portugal constitui um dos poucos exemplos em que os antagonismos anglo-americanos aparecem de forma patente. A capital portuguesa e suas ilhas atlânticas estiveram presentes em diversas divergências sobre o controle do Atlântico, sobre a continuidade dos impérios e sobre as futuras relações de força na Europa.

Finalmente, considerando improvável um ataque alemão a oeste e conhecendo os problemas de viabilização de um segundo front na Europa, Londres propôs, poucos meses após a declaração de guerra estadunidense, uma ofensiva no norte da África, o que provocaria uma primeira definição nos interesses estratégicos com relação aos Açores, pois o arquipélago serviria como alternativa a Gibraltar em caso de ataque dos espanhóis como reação a um desembarque no Marrocos ou no caso de Casablanca não ser conquistada rapidamente.

Os estados-maiores anglo-americanos debateram intensamente durante os primeiros meses de 1942, sobretudo porque os estadunidenses sabiam que um desembarque no Magreb representaria um atraso significativo para todas as outras operações na Europa ocidental e um desvio de recursos para o Mediterrâneo. Entretanto, os argumentos ingleses eram consistentes e os estadunidenses viram-se forçados a reconhecer que ainda não era possível abrir um segundo front na Europa com as forças disponíveis no momento.

Desse modo, durante o mês de abril de 1942, iniciaram-se algumas diretas, porém discretas, tratativas partindo de Washington para obter, perante os portugueses, quando necessário, os Açores como base aeronaval. ${ }^{47}$ Salazar, rejeitando de pronto tais demandas, teria procurado no governo inglês um apoio para resistir às pressões dos Estados Unidos.

\footnotetext{
${ }^{45}$ FOHLEN, Claude. L'Amérique de Roosevelt. Paris: Imprimerie Nationale, 1982, p. 227. NOUAILHAT, Yves-Henri. Les Etats-Unis et le monde au 20è siècle. $2^{\mathrm{a}}$ ed. Paris: Armand Colin, 2000, p. 147. ${ }^{46}$ O áudio do discurso de 6 de março de 1946, em Fulton no Estados Unidos, em que Churchill cunhou publicamente a célebre expressão "special relationship" pode ser acessado em: http:// www.churchill-speeches.com/speech player/index.htm Acesso em: 08/01/2009.

${ }^{47}$ AMFNE - Série Guerre 1939-1945 - Vichy, sub-série Europe, vol. 662. Telegramas n ${ }^{\text {os }}$. 714716, datados de 25/04/1942, da Legação da República Francesa em Lisboa ao Ministério dos Negócios Estrangeiros em Vichy.
} 
Mesmo com Washington tomando algumas iniciativas com relação ao arquipélago, a Inglaterra ainda mantinha o papel de ator principal e de intermediário indispensável para as negociações com Lisboa em virtude da Aliança Secular, da percepção de Salazar sobre as potências mundiais e de seus fortes preconceitos com relação à administração estadunidense..$^{48}$ Os respaldos ingleses confortaram o líder português que, a essa altura, temia mais uma ação estadunidense sobre os Açores que uma alemã, o que poderia levá-lo a tomar posição ao lado do Eixo. ${ }^{49}$ Tranquilizar Lisboa era uma das medidas mais importantes a tomar no momento para o gabinete inglês, no qual Salazar depositava muita confiança. A esse contexto, somam-se as pretensões muitas vezes pouco discretas dos ingleses de manter forte seu prestígio e distantes os estadunidenses, levando-os a iniciar um duplo jogo no solo português, acirrando as diferenças anglo-americanas.

\section{A Operação Torch}

Ao fim de julho de 1942, mesmo restando inalterada a previsão de um grande desembarque na França, Roosevelt finalmente acolheu os argumentos de Churchill sobre atacar os flancos da Europa e invadir o Magreb, operação batizada de Torch ${ }^{50}$ Quanto a uma reação alemã, seja por causa das resistências colocadas pelo líder espanhol para entrar em guerra ao lado do Eixo, seja por causa dos maus resultados das campanhas no front russo, o perigo de um ataque à península Ibérica (o plano Félix) ${ }^{51}$ fora reduzido.

Lançada a Operação Torch e com a passagem de Casablanca para o lado dos Aliados, a ocupação preventiva dos Açores perdia momentaneamente seu interesse, embora sua importância para a guerra submarina restasse notória, sobretudo porque, com o front africano, aumentou o fluxo de comboios vindos dos Estados Unidos em direção ao Mediterrâneo. De fato, a partir de dezembro de 1942, os combates tiveram lugar no seio do Atlântico, frequentemente

\footnotetext{
${ }^{48}$ AMFD - Série 2 BB7 Li 3 - 1939/1947. Carta n. 451, datada de 14/09/1942, do adido naval da Legação francesa em Portugal ao almirantado francês, Marinha.

${ }^{49}$ AMFNE - Série Guerre 1939-1945 - Vichy, sub-série Europe, vol. 662. Resumo de informação n. 19, datado de 26/05/1942, do adido naval francês da Legação da República Francesa em Lisboa ao Ministério dos Negócios Estrangeiro em Vichy.

${ }^{50}$ GIRAULT, René; FRANK, Robert; THOBIE, Jacques, op. cit., 2005, p. 44.

${ }^{51}$ Operação prevista nas diretivas $\mathrm{n}^{\text {os }} .18$ e 19, emitidas por Hitler no fim de 1940, estabelecendo um ataque a Gibraltar que, se concretizado, alteraria toda a situação na península Ibérica e nas possessões atlânticas portuguesas. Hitler's war directives 1939/1945. $5^{\text {a }}$ ed. Londres: Editions H. R. Trevor-Roper, 1983, p. 87-88.
} 
perto dos Açores. Não por menos, apesar das garantias recebidas de Londres e Washington, Salazar temia uma agressão contra suas ilhas. ${ }^{52}$

O líder português imaginava que romper com os Aliados por causa de uma invasão provocaria a irrupção desses no império e tornaria crítica sua situação em Portugal. Considerando que o país era dependente dos mares e acreditando fortemente que a Inglaterra ainda era a grande potência marítima e imperial do mundo, o governo português julgava que a manutenção da aliança com os ingleses continuava vital. Londres, de fato, ainda mantinha grande influência no país ao deter, por exemplo, concessões de serviço público como transporte e telefonia, e ao aumentar as ações de difusão da língua e da cultura inglesas através do Instituto Britânico.

Entretanto, como consequência da Operação Torch, da presença do exército estadunidense no norte da África e das conquistas japonesas no Pacífico, bloqueando as rotas de abastecimento dos Aliados nesse oceano, mudava a maneira como os Estados Unidos consideravam o Atlântico, Portugal e os Açores.

A guerra avançava e a invasão do continente europeu se aproximava. Pela primeira vez, as ilhas portuguesas representavam efetivamente para Washington uma importante base ativa, não mais para a defesa do hemisfério, mas para o abastecimento de suas próprias forças (a utilização das bases aéreas dos Açores permitiria dobrar as cargas transportadas entre a América e a Europa-África).

Em virtude dessa mudança de perspectiva, iniciava-se uma disputa ainda mais acirrada não somente entre os Aliados, mas entre vários níveis da administração de cada país envolvido, como se viu na série de pressões dos militares anglo-americanos sobre seus diplomatas para que novas negociações com Lisboa fossem providenciadas. Na Inglaterra, o Foreign Office, responsável pelos canais de comunicação com Salazar, recusa tal empreitada e reclama, antes, a expulsão total dos alemães da África, pois para eles ainda era preciso manter estável a neutralidade portuguesa. ${ }^{53}$

Mesmo com o Estado-maior britânico não tomando posição oficial a esse respeito, a fim de evitar um conflito institucional, os militares decidem levar diretamente $\mathrm{o}$ assunto a Churchill. A iniciativa foi bem planejada, pois o primeiro ministro tinha consciência das necessidades navais, além de uma grande visão

\footnotetext{
${ }^{52}$ AMFD - Série 2 BB7 Li 3 - 1939/1947. Resumo de informação n. 26, datado de 08/09/1942 do adido naval da Legação francesa em Portugal ao almirantado francês, Marinha.

${ }^{53}$ TELO, Antonio José, op. cit., 1993, p. 377-393.
} 
política, que o fez compreender que a Inglaterra tinha necessidade de agir rapidamente quanto aos Açores, sob pena de que os estadunidenses a antecipassem. ${ }^{54}$

Apesar das rivalidades, os preparativos e os estudos conjuntos para o segundo front prosseguiam. Uma das possibilidades era a de que, assim que as operações na Tunísia terminassem (condição para assegurar a imprescindível liberdade de comunicações no Mediterrâneo) e que a Alemanha estivesse fortemente engajada em seu front oriental, as potências anglo-americanas fariam Portugal entrar em guerra na véspera do desembarque na França, pois a implicação dos Açores, apesar de implícita, seria fundamental. De fato, uma batalha do porte da esperada para a Europa exigiria que o aprovisionamento dos soldados aliados funcionasse intensa e regularmente, sem mencionar a importância do arquipélago para abreviar a guerra submarina que, no início de 1943, entrava em uma fase decisiva (mesmo considerando que, nessa época, não existiam mais "santuários" no meio do oceano em virtude do emprego dos novos porta-aviões de escolta estadunidenses). ${ }^{55}$

No processo de passagem da logística do front africano para a do front europeu, tudo fazia crer que, antes da grande batalha da Europa, dever-se-ia ganhar a batalha do Atlântico no mar ou encontrar uma alternativa pelo ar, sendo que ambas as possibilidades passavam necessariamente pelos Açores. ${ }^{56}$

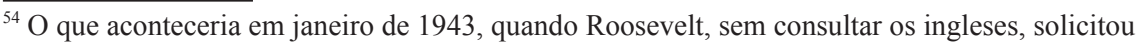
ao presidente Getúlio Vargas que tropas brasileiras substituíssem as portuguesas nos Açores, o que foi, no entanto, recusado. TELO, Antonio José, op. cit., 1993, p. 377-393.

${ }^{55}$ Os porta-aviões de escolta eram pequenas unidades de um pouco mais de 10.000 toneladas que transportavam em média 20 aparelhos. Sua principal missão, como o próprio nome revela, era de escoltar os comboios de abastecimento promovendo sua cobertura aérea (Disponível em: http:// www.navy.mil/navydata/navy_legacy hr.asp?id=3 Acesso em: 08/01/09).

${ }^{56}$ AMFNE - Série Guerre 1939-1945 - Vichy, sub-série Europe, vol. 656. Carta n. 69, datada de 10/03/1943, do responsável de negócios da Legação francesa em Portugal, Pierre Baraduc, a Pierre Laval. Segundo as palavras do embaixador inglês em Lisboa em junho de 1943: "A campanha submarina alemã evoluiu ao ponto de seriamente impedir a plena ação das forças das Nações Unidas no campo de batalha. O governo de Sua Majestade não teme mais que essa ameaça seja um obstáculo à vitória final dos Aliados, mas estima que ela é ainda capaz de atrasar seriamente a vitória. O governo de Sua Majestade reviu a situação à luz desses fatos e, com relação à sua aliança com Portugal, chegou à conclusão que o uso de facilidades nas ilhas portuguesas do Atlântico, particularmente nos Açores, pelos aviões e navios de superfície, constituiria um fator decisivo para uma rápida derrota da campanha submarina alemã e seria, consequentemente, uma contribuição vital a uma vitória rápida das Nações Unidas" (AMFNE - Série Europe 1944-1949 - Portugal, vol. 22. Carta n. 140/RC, datada de 10/07/1946, de m. Du Sault a Georges Bidaut).
} 


\section{A decisiva Conferência de Trident de maio de 1943}

A expectativa de Portugal de ver mais forças militares e diplomáticas das Nações Unidas orientarem-se para o mundo atlântico aumentava mês a mês. ${ }^{57}$ As dificuldades em manter a neutralidade agravavam-se, pois as pressões angloamericanas tinham alcançado um nível nunca antes visto.

Finalmente, Churchill decide tomar medidas imediatas de maneira a evitar que Washington tomasse a dianteira quanto às iniciativas diplomáticas perante Lisboa. A Conferência de Trident, em maio de 1943, seria a ocasião perfeita, em virtude da forte presença de militares (e de poucos diplomatas) ao lado dos homens de Estado. Assim, nas vésperas dessa reunião, a grande questão não era a da pertinência da ocupação dos Açores, mas quem e como a realizaria. Os ingleses e os estadunidenses continuavam rivalizando ao pretenderem liderar essa operação de forma isolada, mas concordavam que seria fundamental obter as ilhas no curto prazo, a fim de abreviar a guerra e proteger suas forças no futuro.

O dossiê de Portugal e das ilhas foi abordado desde as primeiras reuniões do Estado-maior. ${ }^{58}$ As duas partes do Combined Chiefs of Staff (CCS) apresentavam argumentos favoráveis à ocupação das ilhas e pretendiam realizá-la de forma exclusiva. Foi destacada a importância estratégica da cobertura aérea do Atlântico, bem como o fator tempo na progressão das batalhas e, portanto, a não necessidade de que negociações diplomáticas fossem efetuadas perante Lisboa para se ocupar os Açores.

No dia 19 de maio, o caso foi discutido perante Churchill e Roosevelt. Mesmo considerando-se que foi o presidente estadunidense que lançou a ideia de dividir a ocupação com os brasileiros, ambos os líderes concordaram sobre o fato de que Salazar não colaboraria e que a manobra deveria ser realizada o mais rápido possível. Os ingleses voltaram a argumentar que a operação lhes pertencia, pois Portugal se encontrava dentro de sua zona de influência. Seus objetivos eram claros: demonstrar força política e militar ao ressaltar que estavam prontos para agir. Os planos apresentados eram para o mês de agosto de 1943, após a disponibilização das embarcações de assalto utilizadas na Sicília. Finalmente, no nível das iniciativas diplomáticas, Churchill sugeriu que Portugal fosse advertido

\footnotetext{
${ }^{57}$ AMFNE - Série Guerre 1939-1945 - Londres-Alger, vol 1285. Carta n. 19, datada de 03/05/1943. ${ }^{58}$ Arquivos Nacionais do Reino Unido (Public Record Office). PRO CAB 121/153 - "Trident", conference at Washington between UK and USA. Atas das reuniões do CCS ocorridas entre 12 e 25 de maio de 1943 (Parte IV).
} 
somente na véspera do desembarque, o que os estadunidenses aceitaram. No fim do encontro, mesmo considerando que foram os ingleses que obtiveram a operação, os Estados Unidos conquistaram uma concessão muito importante: que as bases fossem disponibilizadas às Nações Unidas, e não somente à Inglaterra. ${ }^{59}$

O balanço de Trident foi favorável a Churchill e a seu Estado-maior. Entretanto, ele continuava sem a anuência de seu gabinete e do Foreign Office. Como a operação somente seria realizada dentro de alguns meses, assim que o secretário de Relações Exteriores, Anthony Eden, tomou consciência dos acordos de Trident, instalou-se um grande conflito com o primeiro ministro para que se fossem feitas diligências prévias perante o governo português para a cessão do arquipélago.

Mesmo não conhecendo Salazar perfeitamente as intenções de Roosevelt e Churchill, nem os resultados de Trident, semana após semana, um ultimato vindo dos Aliados para utilizar as ilhas atlânticas parecia mais certo, com grandes chances de provocar a entrada de Portugal em guerra (a imprensa controlada pregava que "o inevitável pode surgir, simplesmente por causa da evolução das circunstâncias..."). ${ }^{60}$ Provas das tensões crescentes em Lisboa foram as decisões governamentais de maio de 1943: publicação do Regulamento ${ }^{\circ}$ 10.402 do Ministério da Guerra (estabelecendo a censura militar para todas as correspondências do triângulo metrópole-Açores-Madeira), modificações no Código Penal (endurecimento contra delitos que atentassem contra a segurança exterior do Estado) e exercícios de defesa contra ataques aéreos. ${ }^{61}$

O líder português começava a repensar sua política de simpatia com relação ao Eixo ao perceber as mudanças nas relações das forças em guerra e, principalmente, suas consequências políticas. ${ }^{62}$ Ganhavam espaço as preocupações com a influência e a solidariedade existente entre os anglo-americanos e a URSS e com os resultados de uma vitória (também) ideológica dos Aliados sobre a organização de Portugal. O governo italiano, que sempre foi uma referência para Lisboa,

\footnotetext{
${ }^{59}$ Arquivos Nacionais do Reino Unido (Public Record Office). PRO CAB 121/153 - "Trident", conference at Washington between UK and USA. Atas das reuniões plenárias ocorridas entre 12 e 25 de maio de 1943 (Parte II).

${ }^{60}$ AMFD - Série 2 BB7 Li 4 - 1939/1947. Carta n. 11/M, datada de 20/01/1943 do adido naval da Legação francesa em Portugal ao almirantado francês, Marinha.

${ }^{61}$ Baseado no Decreto-Lei n ${ }^{\circ} 32.670$ de 17/02/1943 para a preparação da nação para os tempos de guerra (AMFD - Série 2 BB7 Li 4 - 1939/1947. Carta n. 65/M, datada de 01/06/1943, do adido naval da Legação francesa em Portugal ao almirantado francês, Marinha).

${ }^{62}$ AMFD - Série 2 BB7 Li 4 - 1939/1947. Carta n. 11/M, datada de 20/01/1943, do adido naval da Legação francesa em Portugal ao almirantado francês, Marinha.
} 
passava por complexas dificuldades. Ademais, a estabilidade da península Ibérica e a segurança de Portugal não estavam garantidas, pois o país continuava desarmado (o exército contava somente com uma divisão operacional na metrópole), sem mencionar a situação interior, com rupturas sociais em andamento.

Os primeiros meses de 1943, com as batalhas na Tunísia e em Stalingrado, mostravam o caminho da vitória dos Aliados, mesmo que não se soubesse ainda como aconteceria a derrota alemã. ${ }^{63}$ Ao reconsiderar as mudanças da realidade interior e exterior do seu país, Salazar sabia que seria difícil manter a neutralidade nos antigos moldes.

\section{A crise do verão de 1943}

Portugal entrava em um período de tensão durante o verão de 1943 e uma aproximação com o antigo aliado desenhava-se como a saída mais segura para o presidente do Conselho português por diversas razões, dentre as quais: a necessidade de apoio externo no caso de um futuro conflito com a Espanha (ou de uma intervenção de Hitler), pelo abastecimento do país (abalado pela fome e pela miséria, sintomáticas do bloqueio dos Aliados) ou para reafirmar o controle sobre o exército.

De fato, a presença inglesa em Portugal continuava forte. Os jornais de Lisboa e do Porto dessa época mostram que o espaço ocupado pelos Estados Unidos era particularmente pequeno: além das críticas cinematográficas, onde as estrelas de Hollywood ganhavam destaque, ainda que relativo, outras manifestações reduziam-se a algumas fotos da América e a alguns editoriais de Ernest Hemingway. ${ }^{64}$

Contrariamente, para a cultura inglesa, vários elementos permitiam constatar que, dia após dia, ela ganhava adeptos. Os jornais de Londres conheciam um sucesso de vendas que, antes de 1940, poucos podiam prever. Já o livro inglês, apesar de seu preço extremamente alto para os intelectuais portugueses, era um sucesso de vendas e os estoques esgotavam-se rapidamente nas livrarias. Ademais, as exposições de cinema, a visita de atores britânicos, os cursos de civilização inglesa, as menções na imprensa e as atividades organizadas pelo Instituto Britânico mostravam claramente que as relações culturais anglo-por-

\footnotetext{
${ }^{63}$ GIRAULT, René; FRANK, Robert; THOBIE, Jacques, op. cit., 2005, p. 94-99.

${ }^{64}$ AMFNE - Guerre 1939-1945 - Londres-Alger, volume 1.288. Relatório datado de 29/06/1943, do Instituto Francês em Portugal para o Secretariado dos Negócios Estrangeiros em Alger.
} 
tuguesas eram cada vez mais calorosas e estreitas. Nesse contexto, aumentava o espaço para uma aproximação nas esferas mais altas de poder para uma maior colaboração portuguesa junto a Londres. ${ }^{65}$

Finalmente, em junho de 1943 na capital inglesa, Anthony Eden ganhava o braço de ferro com Churchill que ficara encarregado da difícil tarefa de informar os estadunidenses de que seria preciso negociar pelos Açores. Sem surpresa, Washington recebe muito mal as notícias, sobretudo porque alguns setores de seu exército temiam ser excluídos dos resultados de tais tratativas. A situação inglesa tornava-se delicada. De um lado, para acalmar os espíritos estadunidenses, Churchill ratificava a decisão de Trident de abrir as futuras bases às Nações Unidas, de outro, a ordem era de não mencionar a necessidade de utilização das bases pelas forças estadunidenses perante os portugueses, em razão dos preconceitos de Salazar para com os Estados Unidos. Entretanto, sabendo os ingleses que nada de importante poderiam recusar a Washington, eles resistiriam ao máximo, a fim de não ceder facilmente sua zona de influência, embora a sobrevivência inglesa dependesse cada vez mais de um envolvimento militar estadunidense no Atlântico. ${ }^{66}$ Dessa forma, Londres apresentou ao State Department a exclusão dos Estados Unidos de um eventual tratado internacional como se fosse uma exigência de Salazar e, em 18 de junho de 1943, formalizou perante Lisboa o pedido por bases nos Açores. ${ }^{67}$

Apesar de resistir a tal modalidade de negociação, Washington apoiou Londres e se encarregou igualmente de fazer pressão sobre Lisboa. A necessidade dos Açores para a constituição do segundo front na Europa era tão evidente que seus diplomatas fizeram chegar ao sub-secretário de Estado português, sr. Santos Costa, a ideia segundo a qual a ocupação dos Açores "encurtaria a guerra em pelo menos um ano" ${ }^{68}$ Os dirigentes lusitanos sentiram a deterioração da situação de seu país, ainda mais porque a arma econômica era manipulada pelos Aliados contra os interesses de Lisboa. A Inglaterra não dissimulava mais seu empenho

\footnotetext{
${ }^{65}$ Ibidem.

${ }^{66}$ Ibidem, p. 302.

${ }^{67}$ TELO, Antonio José, op. cit., 1993, p. 393-411.

${ }^{68}$ AMFNE - Guerre 1939-1945 - Londres-Alger, vol. 1.285. Carta n. 1.832/RG, datada de 22/06/1943 do comandante em chefe civil e militar francês - Direção dos Serviços de Informação e do Serviço de Segurança Militar - S. R. Guerra - Alger, dirigida ao C.E.C. F.C.M. $-2^{\circ}$ Bureau - Gabinete - Secretariado dos Negócios Estrangeiros.
} 
em se aproveitar das dificuldades de Portugal (que somente os Aliados tinham capacidade de remediar) para forçar o país a ceder os Açores.

O caso do petroleiro português São Braz foi um exemplo. Ele assegurava o abastecimento de combustível de Portugal e foi imobilizado pelos ingleses por mais de um mês no porto de Lisboa. Da mesma maneira, outro petroleiro, fretado pelo governo, esperou durante mais de dois meses a autorização de partida, sem mencionar os navios que deveriam buscar trigo na Argentina, mas que foram bloqueados por "falta de documentação". 69

Não bastassem as restrições no abastecimento de alimentos, outro dossiê que voltou à tona durante esse período foi o do volfrâmio. Tomando como justificativa as compras ilícitas e os contrabandos alemães diante da tolerância das autoridades portuguesas, o State Department ameaçava empregar severas represálias contra Portugal. ${ }^{70}$ Mesmo que a insatisfação dos Aliados se justificava pela importância estratégica do mineral, no contexto das negociações sobre as bases no arquipélago português, a questão do volfrâmio constituía mais um meio de pressão.

No plano diplomático, o sucesso das Nações Unidas na Tunísia e, em seguida, na Sicília, encorajava o embaixador da Inglaterra a aprofundar as tratativas com as altas esferas do governo de Lisboa. Sem contar que, com o êxito da ofensiva soviética, diminuía o perigo de uma ocupação da península Ibérica pelo exército alemão, embora ainda poucos esperassem uma vitória total dos Aliados (uma derrota incondicional dos alemães não passava de uma esperança e de um objetivo para os anglo-americanos a essa altura).

Outra inquietação dos portugueses era a Força Expedicionária Brasileira que em breve interviria na Itália. Circulavam rumores em Portugal de que o exército brasileiro, composto de "irmãos de raça", poderia ser empregado em operações contra os interesses da "pátria mãe", a qual dificilmente conseguiria resistir. ${ }^{71}$ Com relação a esses boatos, Salazar mostrava-se inquieto e irritado. Ele deixava entender que, em caso de tal eventualidade, ele abriria prontamente suas fronteiras ao Eixo, mesmo sabendo que a Espanha já havia refutado uma autorização para a passagem de tropas alemãs sobre seu território. ${ }^{72}$

\footnotetext{
${ }^{69}$ AMFNE - Série Guerre 1939-1945 - Vichy, sub-série Europe, vol. 662. Carta n. 180, datada de 12/07/1943, da Legação francesa em Portugal ao Ministério dos Negócios Estrangeiros em Vichy. ${ }^{70}$ ROSAS, Fernando, op. cit., 1995, p. 82.

${ }^{71}$ AMFNE-Guerre 1939-1945-Londres-Alger,vol.1.285.Carta datada de 05/07/1943, docônsul francês em Porto, sr. O. D’Alexandry, ao sr. René Massigli, comissário para os Negócios Estrangeiros em Alger.

${ }^{72}$ DUROSELLE, Jean-Baptiste, op. cit., 2001, p. 297.
} 
Apesar das afinidades anglo-portuguesas, da não menção dos interesses estadunidenses por nenhum dos lados e da crise portuguesa, as negociações seguiam em uma tensão crescente até que foram bloqueadas em razão das exigências de Salazar, especialmente por causa de suas pretensões em rearmar e treinar suas tropas antes da cessão das bases, o que levaria meses, tempo de que os ingleses não dispunham. ${ }^{73}$

Contudo, as renitências do líder português seriam enfraquecidas pelo agravamento da crise alimentar e pelas pressões internas sobre o governo. Após a queda de Mussolini, no fim de julho de 1943, cujo modelo de Estado havia inspirado o regime português, greves e protestos em massa explodiram ao norte do país, ${ }^{74}$ levando Salazar a considerar a tomada de partido em favor dos Aliados como sua única salvação.

Condicionar a neutralidade parecia ser a resposta quando considerada a progressão das batalhas no continente europeu. Com a fragilidade cada vez mais clara demonstrada pelo regime francês, sobre o qual também se apoiava a política exterior portuguesa e que Salazar via como um parceiro primordial nos planos para uma futura Europa autoritária, corporativista e cristã, ${ }^{75}$ e com as relações cada vez mais tensas com Tóquio, em função da opressão de oficiais portugueses no Timor, os adversários internos da neutralidade juntavam-se aos Aliados e aumentavam a pressão sobre Lisboa. ${ }^{76}$

A crise parecia insolúvel, a menos que os Aliados (que decididamente não desejavam a derrubada do regime por temerem a instabilização da península) procedessem a uma manobra imediata de salvamento. Oferecer uma relativização da política de neutralidade era a saída para Salazar para assegurar o abastecimento de sua população e a salvação de seu império e de seu regime. Assim, já durante o mês de agosto de 1943, a imprensa local, controlada pelo governo, começava a preparar a opinião pública para o acordo sobre as bases que se desenhava. A Aliança Secular, a importância da guerra aérea empregada

\footnotetext{
${ }^{73}$ TELO, Antonio José, op. cit., 1993, p. 398.

${ }^{74}$ ROSAS, Fernando, op. cit., 1995, p. 380-387.

${ }^{75}$ JANEIRO, Helena Pinto. Salazar e Pétain: Relações luso-francesas durante a II Guerra Mundial (1940-44). Lisboa: Edições Cosmos, 1998, p. 114.

${ }^{76}$ Os ingleses utilizaram até mesmo o caso do Timor como moeda de troca, pois eles sabiam que Salazar não teria forças suficientes para vencer os japoneses e para manter a soberania de sua possessão no futuro sem a ajuda de tropas britânicas (AMFNE - Série Guerre 1939-1945 - Vichy, subsérie Europe, vol. 662. Telegramas $n^{\text {os }} .370-371$, datados de 29/07/1943, do sr. Monnier a Laval).
} 
pelas Nações Unidas e suas investidas vitoriosas contra os territórios do Eixo começavam a ser evocadas de maneira explícita. ${ }^{77}$

A mudança de posição seria clara: a aliança inglesa restaria mais claramente "no topo" dos interesses da diplomacia portuguesa, posição que nenhuma outra nação tinha ocupado até esse momento durante todo o período da guerra. ${ }^{78}$ As negociações chegavam ao fim e o Estado-maior do exército português já planejava modificações profundas na concepção de neutralidade tal como ela fora interpretada até o momento. A aliança inglesa tomaria no futuro próximo uma "nova significação" para Portugal. ${ }^{79}$

\section{Colaboração, a neutralidade condicionada}

Finalmente, no dia 17 de agosto de 1943, foi assinado secretamente o tratado prevendo a cessão de facilidades nas bases aeronavais dos Açores. $\mathrm{O}$ acordo assegurava a isenção dos Aliados nos assuntos internos de Portugal e os recursos de que o país precisava que, sozinho e preso a uma neutralidade anacrônica, Salazar seria incapaz de conseguir. ${ }^{80}$

As greves e os protestos que marcaram a crise do verão de 1943 mostraram ao chefe de governo português o perigo de uma desestabilização interna de seu país se a Inglaterra, que a seus olhos ainda dispunha de meios econômicos, políticos e morais poderosos, tivesse um dia interesse em utilizá-los para derrubar o regime. Contudo, o acordo com a democracia inglesa confirmava o caráter aceitável de seu autoritarismo e dava-lhe um precioso apoio moral no futuro próximo. A posição aparentemente precária do presidente do Conselho reafirmavase vigorosamente sobre novas bases a partir da assinatura do acordo. ${ }^{81}$

\footnotetext{
${ }_{77}$ AMFD - Série 2 BB7 Li 4 - 1939/1947. Carta n. 75/M, datada de 22/06/1943, do adido naval da Legação francesa em Portugal ao almirantado francês, Marinha.

${ }^{78}$ AMFNE - Série Guerre 1939-1945 - Vichy, sub-série Europe, vol. 662. Carta n. 162, datada de 01/08/1943, do ministro da França em Portugal ao Ministério dos Negócios Estrangeiros.

${ }^{79}$ AMFNE - Guerre 1939-1945 - Londres-Alger, vol. 1.285. Carta n. 2.047, datada de 13/08/1943, da missão do Comitê Francês de Liberação Nacional em Portugal ao sr. Massigli, embaixador da França, comissário para os Negócios Estrangeiros em Alger.

${ }^{80}$ Para uma perspectiva diferente, que privilegia fortemente a autonomia e soberania portuguesas quando da decisão pela "neutralidade colaborante", ver: ANDRADE, Luis. A Aliança inglesa e a neutralidade colaborante de Portugal. In : Boletim do Instituto Histórico da Ilha Terceira, vol. LI-LII. Angra do Heroísmo, 1993-1994, especialmente p. 26-31.

${ }^{81}$ AMFNE - Guerre 1939-1945 - Londres-Alger, vol. 1.285. Carta n. 145, datada de 09/10/1943, do sr. Clarac, secretário de Embaixada, chefe da missão do Comitê Francês de Liberação Nacional em Portugal, ao sr. Massigli, embaixador da França, comissário para os negócios estrangeiros em Alger.
} 
O aprovisionamento do exército português previsto no tratado produziu um efeito considerável sobre a população. $\mathrm{O}$ material de guerra (destinado ao aparelhamento de três divisões e à montagem de um sistema de proteção contra ataques aéreos) era composto sobretudo de veículos de transporte, de tanques leves e médios, de baterias antiaéreas e antitanques e de armas automáticas. Eles foram transportados até Lisboa em cerca de vinte navios cargueiros, cuja entrada no Tejo, acompanhados de uma escolta de corvetas e de contratorpedeiros, em uma calma tarde de um domingo de outono na capital portuguesa, permitiu uma demonstração de força do regime antes da divulgação pública da cessão dos Açores, evitando, assim, que a oposição utilizasse politicamente o acordo e alegasse uma "venda" do arquipélago. ${ }^{82}$

Em razão da quantidade de armamentos, um observador menos advertido poderia pensar que Portugal tinha saído totalmente da neutralidade. Na verdade, o temor do governo diante do avanço soviético e de uma provável "guerra civil europeia" foi também fundamental para posicionar Salazar ao lado dos Aliados e não do Eixo, mesmo se uma maior abertura continuava impedida pela manutenção oficial do status de neutralidade.

Finalmente, ao fim do mês de outubro de 1943, diante da Câmara dos Comuns, Churchill anunciava publicamente o acordo com Portugal:

Eu tenho uma declaração a fazer à Câmara em relação ao tratado assinado, em 1373, entre a Grã-Bretanha e Portugal por sua majestade o rei Eduardo III e, do outro lado, o rei Fernando e a rainha Leonor. (...) $\mathrm{O}$ artigo $1^{\circ}$ do tratado de 1373 declara:

"Em primeiro lugar, nós fixamos e concordamos que a partir deste dia existirá entre nós uma amizade, uma união e uma aliança verdadeiras, fiéis e constantes, mútuas e perpétuas, bem como uma afeição sincera, que, como verdadeiros e fiéis amigos, nós seremos de agora em diante amigos e inimigos de nossos amigos e inimigos recíprocos, e que nós nos suportaremos mutuamente ajuda e assistência em mar e em terra contra os homens ao longo dos séculos.

Este acordo em vigor há mais de 600 anos é sem paralelo na história do mundo. (...) Fundando-se sobre essa antiga aliança, o governo de sua majestade demandou agora ao governo português de conceder-lhe algumas facilidades nas ilhas dos Açores... ${ }^{83}$

\footnotetext{
${ }^{82}$ AMFNE - Guerre 1939-1945 - Londres-Alger, vol. 1.285. Nota datada de 09/09/1943 da Comissão para os Negócios Estrangeiros em Alger.

${ }^{83}$ Sir Winston Churchill, em seu pronunciamento na Câmara dos Comuns sobre os acordos celebrados com Portugal sobre os Açores (AMFNE - Série Guerre 1939-1945 - Londres-Alger, vol. 1.285. Passagem de periódico datado de 12/10/1943).
} 
A aproximação luso-inglesa restava mais forte do que a luso-americana. Contudo, os estadunidenses, impedidos de participar das negociações, receberam muito mal os resultados e não aceitaram a desculpa baseada nos preconceitos de Salazar apresentadas por Londres para justificar a exclusão direta de Washington da assinatura do tratado. Os protestos estadunidenses certamente não eram inconsequentes, pois a cada mês aumentava a importância da rota aérea central do Atlântico, na qual os Açores constituíam uma escala vital.

Tanto foi assim que, exatamente na mesma época, os Estados Unidos aprovavam o projeto de criar uma potente força de aviões B-29 (bombardeiros pesados) ${ }^{84}$ para operar contra o Japão a partir da China (pois a Marinha estadunidense ainda não tinha conquistado as ilhas do Pacífico, as futuras bases dos B-29), estratégia fundamental para vencer os japoneses.

Nesse contexto, uma ligação aérea através da Índia seria a única forma de manter o aprovisionamento de peças dos B-29 nas bases chinesas e, para tanto, o Air Transport Command (companhia de transporte militar criada pela Army Air Force) começou a pressionar fortemente o governo estadunidense a fim de explorar a rota central atlântica, a ligação aérea mais eficaz entre os Estados Unidos e a Índia, viabilizada essencialmente pelas bases nos Açores. ${ }^{85}$

As suspeitas dos Estados Unidos de que o país era conduzido rumo a uma estratégia de preservação da potência e do império britânico na Europa, que não os interessava de forma alguma, foi reforçada pelo caso dos Açores, aumentando as pressões no seio da administração estadunidense para uma maior autonomia com relação à Inglaterra. Os efeitos dessa nova estratégia (certamente também motivada por outras razões, as quais não serão aqui tratadas dado o formato do presente trabalho) já seriam sentidos na Conferência de Teerã no fim de 1943, com a rejeição de várias proposições britânicas por Roosevelt e também por Stálin. ${ }^{86}$

Já a Alemanha poderia ter exercido violentas represálias contra Portugal que ofereceria um alvo fácil à Luftwaffe. Entretanto, não convinha ao Reich, em um momento de dificuldades de efetivos na sequência de batalhas na Itália e na URSS, criar outro front e lançar-se em uma campanha peninsular que exigiria o emprego de reservas indispensáveis para defender a fortaleza europeia, sem mencionar o fato de que Berlim poderia perder um importante canal de abasteci-

\footnotetext{
${ }^{84}$ DURFOUR, Jean-Louis; VAÏSSE, Maurice, op. cit., 2003, p. 56-58.

${ }^{85}$ TELO, Antonio José, op. cit., 1993, p. 437.

${ }^{86}$ Para mais informações, ver : GIRAULT, René; FRANK, Robert; THOBIE, Jacques, op. cit., 2005, p. 99-105.
} 
mento de alimentos e de volfrâmio e uma via de comunicação fundamental com o restante do mundo (Lisboa). Além disso, os alemães poderiam (e o fizeram) aproveitar a oportunidade para buscar benefícios políticos e econômicos. Dessa forma, a única manifestação foi a publicação de uma mensagem de protesto. ${ }^{87}$

Para a Espanha, a posição tomada por Salazar de colaborar com os Aliados, em princípio, parecia modificar a política anterior de Lisboa, o que comprometeria o tratado luso-espanhol de 1939-40 que previa consultas mútuas em caso de incidente podendo comprometer a integralidade do território de cada signatário e que, consequentemente, garantiria a neutralidade dos dois países. ${ }^{88}$

De fato, o presidente do Conselho português não era ingênuo a ponto de negligenciar as vantagens morais que surgiam da amizade entre Madri e Lisboa, mesmo se ela perdia muito do seu interesse político e estratégico. Nesse contexto, ao fim de 1943, a Espanha, cuja aproximação com os Aliados não se daria tão facilmente e tão rapidamente como a de seu vizinho, surgia na retaguarda de Portugal.

Mais hábil, o governo português orgulhava-se de mostrar o caminho a Madri. Os abundantes envios, intencionalmente públicos, de material de guerra inglês a Portugal tinham também como objetivo advertir discretamente os espanhóis; mais do que um elemento de peso na estratégia militar interaliada, era uma maneira de forçar a Espanha a não ceder a uma eventual pressão da Alemanha e a recusar ao Reich bases ou direitos de passagem, ou mesmo uma colaboração militar que poderia ser reclamada. ${ }^{89}$ Entretanto, Salazar não havia deixado de manter conversações com Franco, mesmo se por vezes somente às vésperas

\footnotetext{
${ }^{87}$ Apesar da tenacidade das palavras, a reação do Reich restringiu-se a esta nota: "A Wilhemstrasse entregou, por intermédio de sua legação em Lisboa, uma nota oficial ao governo português. Nessa nota, ela formula o mais vivo protesto contra o fato de ele ter cedido às pressões inglesas que levaram ao estabelecimento de bases nos Açores. Tal acordo é considerado como uma gravíssima violação da neutralidade e, nessas condições, o governo do Reich reserva-se o direito de tomar as medidas que estimará oportunas" (AMFNE - Guerre 1939-1945 - Londres-Alger, vol. 1285. Carta n. 100, datada de 18/10/1943, do sr. Jacques Truelle, ministro da França na Espanha ao sr. Massigli, embaixador da França, comissário para os Negócios Estrangeiros em Alger).

${ }^{88}$ AMFNE - Guerre 1939-1945 - Londres-Alger, vol. 1.285. Carta n. 145, datada de 09/10/1943, do sr. Clarac, secretário de Embaixada, chefe da missão do Comitê Francês de Liberação Nacional em Portugal, ao sr. Massigli, embaixador da França, comissário para os Negócios Estrangeiros em Alger. ${ }^{89}$ AMFNE - Guerre 1939-1945 - Londres-Alger, vol. 1.288. Carta n. 5.538/RG, datada de 18/10/1943, do comandante em chefe do Comitê Francês de Liberação Nacional em Alger ao Comissariado para os Negócios Estrangeiros.
} 
das tomadas de decisões. Efetivamente, diante do avanço das batalhas, o líder espanhol nada poderia fazer contra a aproximação luso-britânica.

A política portuguesa evoluía, mas Lisboa não previa uma alteração forte a ponto de levar o país ao estado de beligerância. Dessa forma, viram-se muitos esforços da parte do governo para contextualizar o tratado das bases e a manutenção da política exterior, agora condicionada ao desenvolvimento da Aliança Secular. Mais do que nunca, ressaltava-se que a neutralidade não deveria existir fora do espaço e do tempo e que ela não era um privilégio nem o resultado do acaso e, surpreendentemente, que ela tinha sido conduzida, desde seu início, em harmonia com os compromissos internacionais que implicavam a fidelidade portuguesa à aliança inglesa..$^{90}$

Dessa forma, o tratado foi divulgado pelo governo português como uma solução temporária e capaz de melhor proteger a navegação mercante no Atlântico. ${ }^{11}$ Nenhuma menção pública a uma utilização ofensiva militar foi feita. Em seu discurso de 25 de novembro de 1943, Salazar tentou claramente mostrar que a neutralidade portuguesa nunca deixou de ser condicionada pelo respeito dos interesses nacionais e pelos compromissos resultantes da Aliança Secular com a Inglaterra. O líder ressaltou "a lealdade tradicional do povo português a suas amizades e aos tratados seculares que o ligam à nação britânica" ${ }^{\text {"92 }} \mathrm{e}$ buscou tornar compatível a decisão de ceder os Açores com a atitude beligerante do Brasil, além de responder às inquietudes espanholas enviando a seu vizinho uma mensagem explicando que a política ibérica sempre fora considerada pelos portugueses como um elemento essencial de sua política externa.

Os últimos anos da Segunda Grande Guerra continuariam a ver o aprofundamento da aproximação dos portugueses com os anglo-americanos, sobretudo por pressão de Washington, pois os Estados Unidos sabiam que, mesmo se eles pudessem operar nos Açores secretamente e debaixo da cobertura inglesa, eles teriam que se submeter ao comando militar de Londres, além de ter que renunciar a seus projetos estratégicos de dominação do Atlântico para o pós-guerra.

\footnotetext{
${ }^{90}$ AMFD - Série 2 BB7 Li 4 - 1939/1947. Carta n. 102/M, datada de 20/09/1943, do adido naval da Legação francesa em Portugal ao secretário de Estado da Marinha.

${ }^{91}$ AMFNE - Série Guerre 1939-1945 - Vichy, sub-série Europe, vol. 662. Carta n. 271, datada de 14/10/1943, do ministro da França em Portugal ao Ministério dos Negócios Estrangeiros.

${ }^{92}$ AMFD - Série 2 BB7 Li 4 - 1939/1947. Carta n. 140/M, datada de 02/12/1943, do adido naval da Legação francesa em Portugal ao secretário de Estado da Marinha.
} 
A imprensa portuguesa não deixou certamente de elogiar a aproximação luso-inglesa, sustentando quase que à unanimidade a decisão de Salazar. ${ }^{93}$ Entretanto, mesmo se esse discurso se repetia na Inglaterra, a partir de 1944 o gabinete português começaria a dar sinais de reconhecimento da crescente, e cada vez mais incontestável, potência estadunidense. O futuro próximo de Portugal estava definido e seu breve momento de autonomia externa tinha acabado.

\section{Referências bibliográficas}

\section{Arquivos:}

Arquivos do Ministério Francês dos Negócios Estrangeiros - Quai d'Orsay:

Série EU-Europe-1944-1949. Portugal, vol. 22.

Série Guerre 1939-1945. Londres-Alger, vols. 1.285 e 1.288.

Série Guerre 1939-1945. Vichy. Sub-série Europe, vols. 656 e 662.

Arquivos do Ministério Francês da Defesa - Château de Vincennes:

Attachés navals liaisons et missions navales. 1939-1947. 2 BB7 Li, vols. 3 e 4. Arquivos Nacionais do Reino Unido - Public Record Office:

PRO CAB 121/153 - "Trident", conference at Washington between UK and USA. Ministério dos Negócios Estrangeiros de Portugal. Dez anos de política externa (1936-1947): a nação portuguesa e a Segunda Guerra Mundial. 15 volumes, Lisboa: Imprensa Nacional, 1961-1992.

Hitler's war directives 1939/1945.5ª edição, Londres: Editions H.R. Trevor-Roper, 1983.

\section{Bibliografia}

ANDRADE, Luis Manuel Vieira de. Os Açores, a Segunda Guerra Mundial e a Nato. Ponta Delgada: Impraçor, 1992.

ANDRADE, Luis Manuel Vieira de. A importância geoestratégica dos Açores nas duas guerras mundiais. In: Boletim do Instituto Histórico da Ilha Terceira, vol. XLV, tomo I. Angra do Heroísmo, 1988, p. 1.389-1.397.

ANDRADE, Luis Manuel Vieira de. AAliança inglesa e a neutralidade colaborante de Portugal. In: Boletim do Instituto Histórico da Ilha Terceira, vol. LI-LII. Angra do Heroísmo, 1993-1994, p. 13-31.

BARROS, Julia Leitão. Anglofilia e germanofilia em Portugal durante a Segunda Guerra Mundial.In:CARRILHO, Maria(org.).Portugalna Segunda Guerra Mundial:Con-

\footnotetext{
${ }^{93}$ AMFD - Série 2 BB7 Li 4 - 1939/1947. Carta n. 117/M, datada de 13/10/1943, do adido naval da Legação francesa em Portugal ao secretário de Estado da Marinha.
} 
tributos para uma reavaliação. Lisboa: Publicações Dom Quixote, 1989, p. 91-136. CARRILHO, Maris; ROSAS, Fernando (org.). Portugal na Segunda Guerra Mundial: Contributos para uma reavaliação. Lisboa: Dom Quixote, 1989.

CERVO, Amado Luiz; BUENO, Clodoaldo. História da política externa do Brasil. $2^{\mathrm{a}}$ ed. Brasília: Editora Universidade de Brasília, 2002.

CONN, Stetson; FAIRCHILD, Byron. The framework of Hemisphere Defense. Washington D. C.: Center of Military History, 1989.

CONNELLY, Matthew. A diplomatic revolution. Nova Iorque: Oxford UP, 2002.

DE GAULLE, Charles. Mémoires de guerre, $3^{\circ}$ tomo. Paris: Plon, 1959.

DOISE, Jean; VAISSE, Maurice. Diplomatie et outil militaire 1871-1969. Paris: Imprimerie Nationale, 1987.

DUFOUR, Jean-Louis; VAISSE, Maurice. La guerre au XXe siècle. Paris: Hachette Livre, 2003.

DUROSELLE, Jean-Baptiste. Historie des relations internationales de 1919 a 1945, tomo I. $12^{\mathrm{a}}$ ed. Paris: Dalloz, 2001.

DUROSELLE, Jean-Baptiste. Todo império perecerá. Brasília: Editora Universidade de Brasília, 2000.

FERREIRA, José Medeiros. Os Açores nas duas guerras mundiais. In: Boletim do Instituto Histórico da Ilha Terceira, vol. XLV, tomo I. Angra do Heroísmo, 1988, p. 73-90.

FOHLEN, Claude. L'Amérique de Roosevelt. Paris: Imprimerie Nationale, 1982.

GADDIS, John L. The United States and the origins of the Cold War (1941-1947). Nova Iorque: Columbia UP, 2000.

GIRAULT, René; FRANK, Robert. Turbulente Europe et nouveaux mondes 19141941. Paris: Edições Payot \& Rivages, 2004.

GIRAULT, René; FRANK, Robert. La puissance française en question 1945-1949. Paris: Publicações da Sorbonne, 1988.

GIRAULT, René; FRANK, Robert; THOBIE, Jacques. La loi des géants. Paris: Edições Payot \& Rivages, 2005.

JANEIRO, Helena Pinto. Salazar e Pétain: Relações luso-francesas durante a II Guerra Mundial (1940-44). Lisboa: Edições Cosmos, 1998.

KOLKO, Gabriel; KOLKO, Joyce. The limits of power: The World and United States Foreign Policy (1945-1954). [s. 1.]: Harper \& Row, 1972.

LEFFLER, Melvyn P. National Security and US Foreign Policy. In: LEFFLER, Melvyn P.; PAINTER, David S (org.). Origins of the Cold War: An international history. $2^{\mathrm{a}}$ ed. Nova Iorque: Routledge, 2007, p. 15-41.

MAY, Ernest R. The decline of diplomatic history. In: BILLIAS, George Athan; GROB, Gerald N. (org.). American history: Retrospect and prospect. Nova Iorque: [s. n.], 1971. 
NOUAILHAT, Yves-Henri. Les Etats-Unis et le monde au 20e siècle. $2^{\mathrm{a}}$ ed. Paris: Armand Colin, 2000.

PEREIRA, Pedro Cantinho. Portugal e o início da construção europeia (1947-1953). [s. 1.]: Ministério dos Negócios Estrangeiros de Portugal, 2006.

RENOUVIN, Pierre; DUROSELLE, Jean-Baptiste. Introduction à l'histoire des relations internationales. $4^{\mathrm{a}}$ ed. Paris: Armand Colin, 1991.

REYNOLDS, David. From World War to Cold War. Nova Iorque: Oxford UP, 2007.

ROLLO, Fernanda. Portugal e o Plano Marshall. Lisboa: Editorial Estampa, 1994.

ROSAS, Fernando. Portugal entre a paz e a guerra 1939 - 1945. Lisboa: Editorial Estampa, 1995.

ROSAS, Fernando. Osalazarismoe aAliançaLuso-Britânica.Lisboa:Fragmentos, 1988.

SOUTOU, Georges-Henri. La guerre de cinquante ans: Les relations Est-Ouest 1943-1990. Paris: Librairie Arthème Fayard, 2001.

STONE, Glyn. The oldest Ally: Britain and the Portuguese connection (1936-1941). Grã-Bretanha: The Royal Historical Society, 1994.

STONE, Glyn. The official British attitude to the Anglo-Portuguese Alliance, 1910-1945. In: Journal of Contemporary History, volume 10, ${ }^{\circ}$ 4. Londres, outubro 1975, p. 729-746.

TELO, Antonio José. Os Açores e o contrôlo do Atlântico (1898/1948). Lisboa: Asa Literatura, 1993.

TELO, Antonio José. Portugal na Segunda Guerra (1941-1945). Lisboa: Vega, vol. I, 1991.

WEINBERG, Gerhard. A world at arms. Cambridge: Cambridge UP, 1994.

\section{Internet:}

Áudio do discurso de 6 de março de 1946, em Fulton no Estados Unidos, em que Churchill cunhou publicamente a célebre expressão "special relationship". Disponível em: http://www.churchill-speeches.com/speech_player/index.htm. Acesso em 08/01/2009.

Declaração de princípios assinada entre o presidente dos Estados Unidos e o primeiro-ministro do Reino Unido (Carta do Atlântico) no dia 14 de agosto de 1941. Disponível em: http://www.nato.int/docu/fonda/b410814a.htm Acesso em: 08/01/09.

Sobre os porta-aviões de escolta da Marinha dos Estados Unidos da América. Disponível em: http://www.navy.mil/navydata/navy_legacy_hr.asp?id=3 Acesso em 08/01/09. 